\title{
Monika Cioch
}

Katedra Technologii Fermentacji i Mikrobiologii Technicznej, Uniwersytet Rolniczy w Krakowie

m.cioch@ur.krakow.pl

\section{Tadeusz Tuszyński}

Katedra Chemii i Toksykologii Żywności, Uniwersytet Rzeszowski

rrtuszyn@cyf-kr.edu.pl

\section{BIOLOGICZNE METODY ODKWASZANIA WIN GRONOWYCH}

\begin{abstract}
Streszczenie: Równowaga między zawartością cukrów i kwasów stanowi najbardziej istotny czynnik w produkcji wysokiej jakości wina. L-jabłczany i L-winiany odgrywają kluczową rolę w procesie winifikacji, wpływając na cechy organoleptyczne napoju oraz jego stabilność fizyczną, biochemiczną i mikrobiologiczną. Odkwaszanie moszczu gronowego i wina jest często niezbędne w jego produkcji, szczególnie w rejonach o niesprzyjających warunkach klimatycznych, do których można zaliczyć również Polskę. Fermentacja jabłkowo-mlekowa indukowana przez bakterie kwasu mlekowego (LAB) skutecznie redukuje kwasowość, jednak przyczynia się do zmiany charakteru wina oraz tworzenia niepożądanych związków, takich jak aminy biogenne czy karbaminian etylu. Alternatywą dla niej jest odkwaszanie z udziałem dobranych szczepów drożdży. Ze względu na ich różnorodność i zmienność genetyczną oraz skuteczność redukcji kwasu jabłkowego w moszczach gronowych i winach, na szczególną uwagę zasługują te szczepy, które zapewniają równocześnie prawidłowy proces fermentacji i dojrzewania. Odkwaszanie win gronowych z udziałem drożdży daje możliwość nie tylko obniżenia kwasowości, ale również uzyskania pożądanych komponentów smaku i aromatu, kształtując jakość sensoryczną finalnego produktu.
\end{abstract}

Słowa kluczowe: odkwaszanie win, LAB, drożdże, kwas L-jabłkowy.

DOI: $10.15611 /$ nit.2014.1.01

\section{Wstęp}

Kwasowość wina pochodzi zasadniczo z dwóch źródeł. Głównym z nich są kwasy organiczne zawarte $\mathrm{w}$ owocach winorośli, przechodzące do moszczu podczas procesu rozdrabniania i tłoczenia. Skład chemiczny winogron wpływa na kompozycję komponentów soku i ostatecznie na końcową jakość produktu. Jedną z kluczowych przyczyn nadmiernej kwasowości wina jest kwas L-jabłkowy, którego zawartość 
w owocach waha się od 1 do $16 \mathrm{~g} / 1$, w zależności od klimatu, regionu, pory roku i odmiany [Redzepovic i in. 2003; Soyer i in. 2003]. Niektóre szczepy winorośli są bogate w L-jabłczany (Zinfandel, Cabernet Franc, Chenin Blanc, Syrah czy Pinot Noir), z kolei u innych dominuje L-winian (Riesling, Semillon, Merlot, Grenache i Palomino). Kwas L-jabłkowy gromadzi się głównie w skórce owoców, zdecydowanie jest go mniej w miąższu i soku winogron. Tendencja ta może ulec zmianie podczas dojrzewania jagód i obróbek technologicznych [Coloretti i in. 2002; Jackson 2008].

Kwas jabłkowy oraz L-winiany stanowią zwykle ponad 90\% całkowitej kwasowości winogron [Kunicka-Styczyńska 2012]. Zawartości L-jabłczanów w jagodach Vitis vinifera są zazwyczaj wyższe w chłodnych regionach winiarskich (15-16 g/l), niska temperatura bowiem spowalnia proces respiracji kwasów, inaczej niż w obszarach charakteryzujących się ciepłym klimatem. Kwas jabłkowy nie tylko przyczynia się do podwyższenia kwasowości wina, ale również służy jako substrat dla szczepów bakterii odkwaszających oraz drożdży, których obecność prowadzi zwykle do niepożądanych zmian produktu po jego rozlaniu do butelek [Delcourt i in. 1995; Pretorius 2000]. Istotne jest zatem usunięcie nadmiaru L-jabłczanu w celu zapewnienia stabilności fizycznej, biochemicznej oraz mikrobiologicznej, co przyczynia się w konsekwencji do poprawy jakości wyprodukowanego wina.

Naturalną metodą uzyskania mniej kwaśnego wina jest biologiczne odkwaszanie, które można osiągnąć zarówno poprzez fermentację mlekowo-jabłkową (MLF), jak i fermentację jabłkowo-etanolową (MEF). Podczas MLF bakterie kwasu mlekowego, m.in. Oenococcus oeni, konwertują kwas jabłkowy do mleczanu i $\mathrm{CO}_{2}$, podczas gdy MEF odbywa się głównie przy udziale drożdży, takich jak Schizosaccharomyces pombe i niektórych szczepów Saccharomyces, przekształcających L-jabłczan do pirogronianu za pomocą wewnątrzkomórkowego enzymu jabłkowego [Fleet 1994; Redzepovic i in. 2003].

Celem pracy było przedstawienie najważniejszych informacji dotyczących metod regulacji kwasowości wina, ze szczególnym uwzględnieniem odkwaszania przy udziale drożdży i bakterii kwasu mlekowego.

\section{Kwasy organiczne w winogronach oraz podczas procesu fermentacji}

Głównymi kwasami organicznymi występującymi w winogronach są L-winian i L-jabłczan. Mimo że związki te mają podobną strukturę chemiczną, syntetyzowane są w owocach z glukozy przy użyciu różnych szlaków metabolicznych. Kwas L-jabłkowy powstaje w reakcji glikolizy i cyklu kwasów trójkarboksylowych (TCA). Produktem pośrednim biosyntezy L-winianu jest natomiast askorbinian. Mniejsze lub większe różnice w kwasowości poszczególnych odmian winorośli wpływają szczególnie na stosunek obydwu kwasów. L-winiany są obecne w owocach zazwyczaj w stężeniach od 5 do 10 g/l, natomiast zawartość kwasu L-jabłkowego w doj- 
rzałych winogronach waha się najczęściej pomiędzy 2 a 6,5 g/l. Jego szczególnie duży nadmiar (15-16 g/l) może wystąpić w owocach zebranych w strefach zimnego klimatu [Volschenk i in. 2006].

Kwas cytrynowy, pomimo śladowej obecności w jagodach (0,5-1 g/l), również odgrywa istotną rolę w procesach biochemicznych i metabolicznych (cykl Krebsa). Opóźnia rozwój komórek drożdżowych, nie powodując jednak ich całkowitej inaktywacji. Oprócz trzech powyższych związków, odpowiadających w głównej mierze za kwasowość winogron, na uwagę zasługują również kwasy fenolowe, pochodne kwasu cynamonowego (kwas kumarowy) oraz kwas glukonowy, występujący w zwiększonym stężeniu w owocach porażonych pleśnią [Ribéreau-Gayon i in. 2006].

L-winiany wykazują odporność na degradację pod wpływem działania mikroorganizmów podczas procesu fermentacji, z kolei kwas jabłkowy i cytrynowy mogą być częściowo metabolizowane przez drożdże i bakterie na drodze konwersji do mleczanu, co skutkuje obniżeniem kwasowości wina [Moreno-Arribas, Polo 2009; Swiegers i in. 2005]. Nawet częściowe przekształcenie kwasu jabłkowego w kwas mlekowy istotnie poprawia smak wina.

Pirogronian należy do jednych z najważniejszych związków organicznych powstałych w wyniku fermentacji moszczu. Śladowa zawartość tego komponentu $\mathrm{w}$ winach spowodowana jest jego przekształceniem przy udziale dehydrogenazy mleczanowej (EC 1.1.1.27) w dwa rodzaje stereoizomerów - kwas L-mlekowy produkowany przez bakterie oraz kwas D-mlekowy wytwarzany przez drożdże. Fosfoenolopirogronian, będący aktywowaną formą enolową kwasu pirogronowego, jest prekursorem kwasu szczawiowego. Ponadto może on ulegać enzymatycznej redukcji do etanolu podczas fermentacji. Innym komponentem produkowanym przez drożdże $\mathrm{w}$ trakcie procesu fermentacji jest kwas bursztynowy (1,4-butanodiowy). W połączeniu z kwasem fumarowym bierze udział w metabolizmie lipidów i cyklu Krebsa. Jego obecność również korzystnie wpływa na cechy sensoryczne wina.

Występujące w moszczach i winach kwasy organiczne należą do hydroksykwasów, rozpuszczalnych w wodzie i alkoholu, odznaczających się stosunkowo wysoką reaktywnością chemiczną, przez co mogą powodować zmiany właściwości wina [Ribéreau-Gayon i in. 2006].

\section{Kwas L-jabłkowy w stadium rozwojowym winorośli}

Rozwój winogron determinują zasadniczo trzy fazy dojrzewania owoców [Terrier $i$ in. 2001]. Pierwsza z nich obejmuje okres zaraz po kwitnieniu winorośli. Charakterystyczne są dla niej twarde, zielone owoce oraz krótki czas podziału komórek i zwiększanie ich rozmiaru, co prowadzi do gwałtownego wzrostu jagód. Ponadto następuje rozrost wakuoli, związany bezpośrednio z magazynowaniem kwasów L-jabłkowego i winowego. Faza II (7-10 tygodni po kwitnieniu) obejmuje krótką lag-fazę, podczas której ustaje wzrost winogron, a ich kwasowość osiąga maksimum 
w wyniku zgromadzenia się L-jabłczanu i L-winianu. Etap III to proces dojrzewania jagód, który rozpoczyna się zwykle 6-8 tygodni po fazie kwitnienia i trwa zazwyczaj od 35 do 55 dni, w zależności od odmiany winorośli. Charakteryzuje się szybkim mięknięciem jagód, gwałtowną akumulacją cukrów i aminokwasów wewnątrz owoców oraz spadkiem kwasowości. W literaturze enologicznej czas przebarwiania się niedojrzałych gron w początkowym okresie dojrzewania określa się mianem veraison, które następuje zwykle szybko, nawet do 24 godzin od rozpoczęcia fazy III [Fillion i in. 1999; Pratelli i in. 2002].

Początek procesu dojrzewania charakteryzują więc zmiany fizyczne i biochemiczne w winogronach, wśród których najważniejsze jest gwałtowne obniżenie kwasowości jagód, co bezpośrednio wiąże się z zawartością w nich większej ilości cukrów. Ponadto, wraz z rozwojem owoców, spowalnia się intensywność oddychania. Dostępność substratu oddechowego, jakim jest sacharoza (w procesie fotosyntezy), zostaje ograniczona ze względu na rozkład chlorofilu. Przesunięty zostaje metabolizm oddychania $\mathrm{z}$ cukru do kwasu L-jabłkowego, który przed okresem dojrzewania występuje najobficiej w wakuoli jagód, przyczyniając się do ich niskiego pH $(2,5)$. Wraz z nadejściem veraison stężenie L-jabłczanów spada (4-6,5 g/l) z jednoczesnym wzrostem $\mathrm{pH}$ owoców (ok. 3,5) [Riberéau-Gayon i in. 2006; Volschenk i in. 2006].

Kwas L-jabłkowy akumuluje się w wakuoli jagód przed okresem dojrzewania za pośrednictwem karboksylazy fosfoenolopirogronianowej (PEPC) i dehydrogenazy jabłczanowej (MDH, EC 1.1.1.40). Cytozolowy enzym PEPC katalizuje ß-karboksylację kwasu fosfoenolopirogronowego, w efekcie czego powstaje kwas szczawiowy i nieorganiczny fosforan [Or i in. 2000]. Otrzymany szczawian w dalszym etapie jest redukowany za pośrednictwem NAD-zależnej dehydrogenazy jabłczanowej w celu biosyntezy kwasu L-jabłkowego. Gwałtowny jego spadek wewnątrz jagód jest wynikiem spowolnienia biosyntezy L-jabłczanu w efekcie jego degradacji poprzez oddychanie. Początkowo zawartość kwasu L-jabłkowego w wakuoli zostaje rozcieńczona w wyniku napływu wody do jagód podczas fazy wzrostu. Ponadto jego degradacja związana jest z syntezą pirogronianu w cyklu kwasów trójkarboksylowych (TCA). Biosynteza kwasu L-jabłkowego przez enzym PEPC jest ograniczona ze względu na brak transkrypcji genu PEPC, który warunkuje rozpoczęcie fazy początku dojrzewania. $\mathrm{W}$ procesie syntezy etanolu z pirogronianu konwersję kwasu pirogronowego do aldehydu octowego przy udziale dekarboksylazy pirogronianowej (PDC) poprzedza redukcja etanalu do etanolu przez dehydrogenazę alkoholową (ADH) [Bucher i in. 1995].

Kwas L-jabłkowy rozkładany jest w moszczu gronowym dwiema drogami - poprzez cytozolowy enzym NADP-jabłkowy oraz w mniejszym stopniu przez karboksykinazę PEP [Or i in. 2000]. Prawdopodobnie degradowany jest on również przez dehydrogenazę jabłczanową (MDH). Szczególnie mitochondrialny izoenzym odgrywa istotną rolę w zredukowaniu zawartości L-jabłczanu w jagodach. Profil ekspresji genu i aktywność enzymu jabłkowego (ME) oraz MDH powodują wzrost ilości kwasu L-jabłkowego w początkowej fazie dojrzewania. Profile ekspresji genów 
i aktywność enzymów ME oraz MDH zmniejszają zawartość kwasu L-jabłkowego we wstępnym okresie veraison. Rozkład L-jabłczanu przez enzym NADP-jabłkowy dostarcza energię wymaganą do biosyntezy i procesów tlenowych, podczas gdy niewielki jego procent $(<5 \%)$ przekształcany jest z powrotem do fosfoenolopirogronianu za pomocą MDH i PEPCK dla syntezy glukozy na drodze glukoneogenezy [Or i in. 2000; Volschenk i in. 2006].

\section{Rola kwasu L-jabłkowego w winie}

Kwasy organiczne i częściowo aminokwasy w głównej mierze warunkują cechy organoleptyczne wina, a szczególnie ich smakowitość. Nadmierna ich koncentracja może przyczynić się do kwaśnego smaku napoju, za co odpowiedzialne są głównie L-jabłczany. Kompozycja kwasów organicznych determinuje pH wina, które oparte jest na równowadze między protonowymi i aprotonowymi izoformami cząstek organicznych, określając zawartość kwasu organicznego i stopień jonizacji aminokwasów w winie. Poziom jonizacji wpływa na ich rozpuszczalność oraz stan aktywności jonowej i biologicznej wielu molekuł, takich jak m.in. białka, kwasy tłuszczowe, związki fenolowe [Volschenk $i$ in. 2006]. Nawet niewielka zmiana $\mathrm{pH}(0,05$ jednostki) skutkuje modyfikacją kwasowości (0,2-0,5 g/l), oddziałując na cechy organoleptyczne napoju [Margalit 1997].

Kwasy organiczne oraz $\mathrm{pH}$ nie tylko determinują rozwój poszczególnych komponentów smakowych, ale również odgrywają istotną rolę w utlenianiu składników wina. Kwasy L-jabłkowy i winowy są odpowiedzialne głównie za hydrolizę nielotnych komponentów fenolowych oraz $\mathrm{C}_{13}$-izoprenoidów pochodzących $\mathrm{z}$ jagód [Volschenk i in. 2006]. Niskie pH $(<3,5)$ zwiększa stabilność wina, hamuje rozwój szkodliwych szczepów bakterii i drożdży, zapobiega procesom oksydacji lub je opóźnia, utrzymując związki fenolowe w stanie niezjonizowanym, w efekcie czego są one mniej podatne na utlenianie i rozwój drobnoustrojów [Winterhalter i in. 1990]. Wartości pH poniżej 2,9 negatywnie oddziałują na mikroorganizmy, w tym Saccharomyces cerevisiae, hamując ich rozwój, ale również opóźniają fermentację alkoholową. W przypadku gdy kwasowość moszczu maleje (pH powyżej 3,5), ryzyko wystąpienia pałeczek mlekowych, pediokoków oraz bakterii Oenococcus oeni gwałtownie rośnie [Alexandre i in. 2004; Bartowshy 2005]. Przedwczesny rozwój bakterii mlekowych stwarza poważne zagrożenie dla jakości wina, co związane jest z przekształcaniem glukozy do kwasów mlekowego i octowego, skutkując podwyższoną kwasowością lotną, redukcją etanolu oraz powolną fermentacją alkoholową [Charoenchai i in. 1998].

\section{Metody regulacji kwasowości wina}

Regulacja kwasowości jest jednym z najważniejszych warunków otrzymania wysokiej jakości wina. Kwasowość ogólna zwykle zwiększa się w procesie fermentacji od 
1 do $2 \mathrm{~g} / 1$ na skutek tworzenia przez szczepy bakterii i drożdży kwasu L-jabłkowego, bursztynowego, octowego i mlekowego [Volschenk i in. 2006]. Ewentualne zakwaszanie moszczu o niskiej kwasowości (wysokie $\mathrm{pH}$ ) jest zabiegiem charakterystycznym dla ciepłych regionów winiarskich i przeprowadza się go przed rozpoczęciem fermentacji alkoholowej. Natomiast w chłodnych regionach winiarskich często potrzebne jest usuwanie nadmiaru kwasu L-jabłkowego lub L-winowego z wina przed lub po fermentacji alkoholowej. Celem takiego zabiegu jest głównie zapewnienie zrównoważonego smaku napoju i właściwej stabilności. Redukcja kwasowości może zostać osiągnięta z wykorzystaniem metod chemicznych lub biologicznych poprzez degradację L-jabłczanu [Zoecklein i in. 1995].

\subsection{Odkwaszanie win przy udziale bakterii mlekowych}

Proces odkwaszania win gronowych przy udziale bakterii mlekowych, opierający się na konwersji kwasu jabłkowego do L-mleczanu na drodze biologicznej, określany jest mianem fermentacji jabłkowo-mlekowej (rys. 1). Reakcja ta zachodzi w obec-

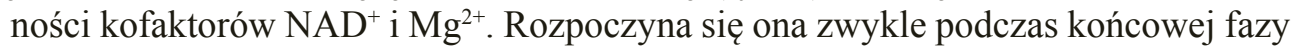
fermentacji alkoholowej, ostatecznie przyczyniając się do obniżenia kwasowości przy niewielkim wzroście $\mathrm{pH}$, poprawy aromatu i smaku wina oraz stabilności mikrobiologicznej [Jitjaroen i in. 2013]. Niekontrolowany proces odkwaszania biologicznego stwarza poważne ryzyko opanowania środowiska przez bakterie heterofermentatywne, wytwarzające uboczne produkty przemiany, takie jak kwas i aldehyd octowy, diacetyl czy mannit, pogarszające jakość produktu [Riberéau-Gayon i in. 2006; Volschenk i in. 2006]. Odkwaszanie win gronowych przebiega przy udziale czystych kultur bakterii mlekowych, głównie szczepu Oenococcus oeni, charakteryzującego się odpornością na niskie $\mathrm{pH}(<3,5)$ oraz wysokie zawartości etanolu ( $>10 \%$ obj.) i $\mathrm{SO}_{2}(50 \mathrm{mg} / \mathrm{l})$. Do mikroorganizmów odpowiedzialnych za proces tzw. fermentacji jabłkowo-mlekowej zaliczyć można również rodzaje Weisella, Lactobacillus, Leuconostoc i Pediococcus [Izquierdo i in. 2008; Moreno-Arribas, Polo 2009; Bartowsky, Borneman 2011; Kučerová, Široky 2011].

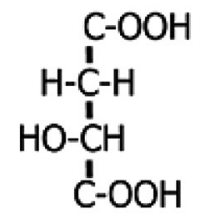

kwas L-jabłkowy

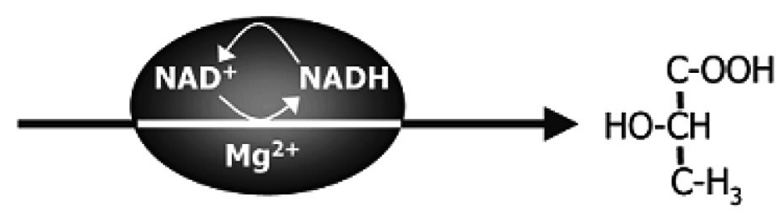

kwas mlekowy

Rys. 1. Rozkład kwasu L-jabłkowego przez bakterie

Źródło: [Volschenk i in. 2006]. 
Bakterie mlekowe stanowią rodzimą mikroflorę owoców winorośli, a reprezentowane są głównie przez gatunki Lactobacillus plantarum, Lactobacillus casei, Leuconostoc mesenteroides i Oenococcus oeni [López i in. 2008]. Podczas pierwszych dni fermentacji alkoholowej ich liczba ulega zwiększeniu $\left(10^{4} \mathrm{jtk} / \mathrm{ml}\right)$, po czym w miarę wzrostu zawartości etanolu i obniżania $\mathrm{pH}$ obserwuje się spadek populacji tych drobnoustrojów $\left(10^{2} \mathrm{jtk} / \mathrm{ml}\right)$ [Moreno-Arribas, Polo 2009]. Związany jest on $\mathrm{z}$ niską temperaturą i $\mathrm{pH}$ we wczesnej fazie procesu, zwiększonym stężeniem etanolu, interakcjami z drożdżami oraz podwyższoną zawartością $\mathrm{SO}_{2}$. Pod koniec fermentacji głównej dominującą mikroflorę stanowią bakterie Oenococcus oeni $\left(10^{7} \mathrm{jtk} / \mathrm{ml}\right)$, które są odpowiedzialne za redukcję kwasowości wina na drodze biologicznego odkwaszania [Volschenk i in. 2006; Capozzi i in. 2010]. Oenococcus oeni, wcześniej klasyfikowany jako Leuconostoc oenos, należy do acydofilnych beztlenowców, optymalnie rozwijających się w temperaturze $18-30^{\circ} \mathrm{C}$ i pH 4,8 . Bakterie te charakteryzują się zwiększoną odpornością na wysoką zawartość alkoholu oraz kwasowość, ponadto sprzyjają tworzeniu pożądanego bukietu zapachowego wina, redukując „roślinne” i „trawiaste” aromaty [Guzzo i in. 1998]. Oenococcus oeni należy do grupy drobnoustrojów heterofermentatywnych, metabolizujących glukozę do kwasów mlekowego i octowego, dwutlenku węgla oraz etanolu. W przeciwieństwie do Pediococcus i Lactobacillus, szczep Oenococcus oeni zdolny jest do prowadzenia biokonwersji przy wartościach pH 3-4 [Osborne, Edwards 2005; Hornsey 2007].

Badania dowodzą, że bakterie fermentacji jabłkowo-mlekowej z rodzaju Oenococcus, Lactobacillus i Pediococcus, wykazujące aktywność glikozydazy, mają istotny wpływ na modyfikację aromatu moszczów i win. Źródłem związków zapachowych $\mathrm{w}$ winogronach są naturalne prekursory aromatu zbudowane $\mathrm{z}$ reszty cukrowej i aglikonowej, połączone wiązaniem $\beta$-glikozydowym. Mogą one również występować jako disacharydy, w których D-glukopiranoza związana jest z $\alpha$-L-arabinofuranozą lub $\alpha$-L-ramnopiranozą. Dotychczasowe badania wykazały, że szczepy Oenococcus oeni i Lactobacillus brevis charakteryzowały się wysoką zdolnością uwalniania związków zapachowych w porównaniu z pozostałymi rodzajami bakterii kwasu mlekowego [Grimaldi i in. 2000; Izquierdo Cañas i in. 2008]. Inne prace potwierdziły znaczące różnice genetyczne LAB, których genotypy charakteryzowały się odmienną zdolnością do metabolizowania kwasu L-jabłkowego [Capello i in. 2008]. Szczepy Oenococcus oeni cechowały się zwykle wysokim wskaźnikiem degradacji L-jabłczanu.

Jednak badania Du Toit i in. [2011] wskazują, że gatunek Lactobacillus plantarum może być alternatywą dla Oenococcus oeni w procesie odkwaszania win. Pozostałe mikroorganizmy z rodzaju Lactobacillus, takie jak Lactobacillus hilgardii, Lactobacillus brevis, Lactobacillus buchneri, przyczyniają się do pogorszenia jakości produktu, a ich obecność objawia się wzrostem kwasowości, mętności oraz tworzeniem niepożądanych aromatów. Szczep Lactobacillus lindneri, zidentyfikowany na owocach winorośli, powoduje wyraźne zahamowanie wzrostu Oenococcus oeni 
Tabela 1. Wpływ metabolizmu bakterii kwasu mlekowego na profil sensoryczny wina

\begin{tabular}{|c|c|c|}
\hline Szczepy bakteryjne & Zalety & Wady \\
\hline $\begin{array}{l}\text { Wybrane szczepy } \\
\text { Oenococcus oeni }\end{array}$ & $\begin{aligned} \text { - } & \text { obniżenie kwasowości } \\
\text { - } & \text { cząstkowa redukcja ketonów } \\
& \text { i aldehydów } \\
\text { - } & \text { poprawa stabilności } \\
& \text { mikrobiologicznej } \\
\text { - } & \text { redukcja trawiastych aromatów } \\
\text { - } & \text { dominacja nad dzikimi } \\
& \text { szczepami }\end{aligned}$ & $\begin{array}{ll}\text { - } & \text { wzrost kwasowości lotnej i pH } \\
\text { - } & \text { utrata koloru } \\
\text { - } & \text { produkcja karbaminianu etylu }\end{array}$ \\
\hline $\begin{array}{l}\text { Spontaniczne szczepy } \\
\text { Oenococcus oеni }\end{array}$ & $\begin{array}{ll}\text { - } & \text { obniżenie kwasowości ogólnej } \\
\text { - } & \text { redukcja ketonów i aldehydów } \\
\text { - } & \text { poprawa stabilności } \\
& \text { mikrobiologicznej } \\
\text { - } & \text { redukcja trawiastych aromatów } \\
& \\
\text { - } & \text { obniżenie kwasowości ogólnej }\end{array}$ & $\begin{array}{ll}\text { - } & \text { wydłużona lag-faza, związana } \\
& \text { ze wzrostem kwasowości lotnej } \\
& \text { zależnej od pH } \\
\text { - } & \text { produkcja diacetylu } \\
\text { - } & \text { wytwarzanie związków } \\
& \text { i aromatów prowadzących do } \\
& \text { zepsucia wina } \\
\text { - } & \text { częściowa degradacja estrów } \\
\text { - } & \text { utrata aromatów odmianowych } \\
\text { - } & \text { pogorszenie koloru poprzez } \\
\text { - } & \text { aktywne polifenole } \\
\text { - } & \text { produkcja amin biogennych } \\
\text { - } & \text { produkcjua arominiáw } \\
\text { prowadzących do zepsucia wina }\end{array}$ \\
\hline $\begin{array}{l}\text { Lacotbacillus } \\
\text { plantarum, } \\
\text { Lactobacillus casei }\end{array}$ & $\begin{aligned} \text { - } & \text { redukcja kwasowości ogólnej } \\
\text { - } & \text { brak wytwarzania kwasu } \\
& \text { octowego z cukru }\end{aligned}$ & $\begin{array}{ll}- & \text { wrażliwe na działanie alkoholu } \\
& \text { ( }>5 \% \text { obj.) } \\
- & \text { spowolnienie lub zahamowanie } \\
& \text { fermentacji } \\
- & \text { wytwarzanie nietypowych } \\
& \text { aromatów }\end{array}$ \\
\hline $\begin{array}{l}\text { Pediococcus } \\
\text { pentosaceus } \\
\text { Pediococcus damnosus }\end{array}$ & $\begin{aligned} \text { - } & \text { redukcja kwasowości ogólnej } \\
\text { - } & \text { brak wytwarzania kwasu } \\
& \text { octowego z cukru }\end{aligned}$ & 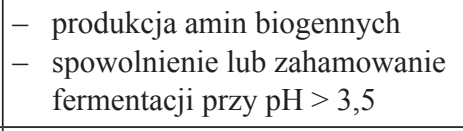 \\
\hline $\begin{array}{l}\text { Lactobacillus brevis } \\
\text { Lactobacillus hilgardii }\end{array}$ & - redukcja kwasowości ogólnej & $\begin{aligned} \text { - } & \text { produkcja amin biogennych } \\
& \text { i karbaminianu etylu } \\
\text { - } & \text { tworzenie niekorzystnych } \\
& \text { aromatów } \\
\text { - } & \text { wytwarzanie kwasu octowego }\end{aligned}$ \\
\hline Lactobacillus kunkeei & & $\begin{array}{ll}- & \text { konkurencja z drożdżami } \\
& \text { podczas fermentacji alkoholowej } \\
& \text { o składniki odżywcze } \\
- & \text { nadprodukcja kwasu octowego }\end{array}$ \\
\hline
\end{tabular}

Źródło: [Bauer, Dicks 2004; Coucheney i in. 2004; Volschenk i in. 2006; Rosi i in. 2009; Malherbe i in. 2011]. 
w zastosowaniu kultur mieszanych. Ponadto wykazuje on zdolność wytwarzania indolu, który nadaje winom posmak sztucznych tworzyw [Capone $\mathrm{i}$ in. 2010].

Inną alternatywą w biologicznym odkwaszaniu moszczów i win może być użycie komórek immobilizowanych. Mikrośrodowisko nośnika wykazuje działanie ochronne na komórki, zapobiegając utrudnieniom przebiegu wtórnej fermentacji wywołanej przez bakterie charakteryzujące się największą wrażliwością na warunki panujące w winie (etanol, polifenole, niskie $\mathrm{pH}$, temperatura). Zdolność degradacji L-jabłczanu zawartego $\mathrm{w}$ winie Chardonnay przez immobilizowane komórki w kuleczkach pektynianu wapnia oraz na powierzchni kuleczek modyfikowanego chitozanu była dwukrotnie większa w porównaniu z komórkami wolnymi [Kosseva i in. 1998]. Korzystne efekty zastosowania komórek immobilizowanych na poliakrylanie potasu oraz w karagenie wykazano również podczas fermentacji brzeczek miodowych [Sroka, Tuszyński 2007]. Natomiast szczepy Oenococcus oeni, unieruchomione w celulozowych gąbkach, metabolizowały ok. 50\% zawartego w winie kwasu jabłkowego w ciągu 24 godzin, wykazując zdolności fermentacyjne jeszcze po 21 dniach przechowywania nośnika w temperaturze $4^{\circ} \mathrm{C}$ [Kosseva i in. 1998; Bonin 2006].

Oddziaływania między bakteriami mlekowymi a drożdżami odgrywają istotną rolę podczas fermentacji wina. Uważa się, że relacje te mogą mieć charakter zarówno hamujący, jak i stymulujący wzrost tych mikroorganizmów. Badania wykazały, że niektóre szczepy drożdży produkują niezidentyfikowane czynniki (być może toksyczne metabolity), które mogą inhibitować wzrost bakterii w wyniku antagonizmu zachodzącego podczas fermentacji jabłkowo-mlekowej tych dwóch grup drobnoustrojów [Satora, Tuszyński 2005]. Doświadczenia Kennes i in. [1991] dowiodły stymulującego działania drożdży Saccharomyces cerevisiae na rozwój bakterii Lactobacillus plantarum [Moreno-Arribas, Polo 2009].

$\mathrm{W}$ tab. 1 przedstawiono zalety i wady biologicznego odkwaszania win z udziałem bakterii kwasu mlekowego.

\subsection{Odkwaszanie win za pomocą drożdży}

Na podstawie zdolności metabolizowania półproduktów cyklu kwasów trikarboksylowych (TCA) jako źródła węgla lub energii drożdże podzielone zostały na dwie grupy K(+) i K(-). Grupa K(-), klasyfikująca szczepy Saccharomyces ssp., Schizosaccharomyces pombe i Zygosaccharomyces bailii, obejmuje drożdże zdolne do wykorzystania półproduktów cyklu TCA wyłącznie w obecności glukozy lub innego przyswajalnego źródła węgla [Rodriquez, Thornton 1990; Thornton, Rodriquez 1996; Saayman, Viljoen-Bloom 2006]. Szczepy Saccharomyces ssp. są zazwyczaj uważane za najmniej efektywnie metabolizujące zewnątrzkomórkowy kwas jabłkowy w przeciwieństwie do Schizosaccharomyces pombe i Zygosaccharomyces bailii, które mogą rozkładać wysokie stężenia L-jabłczanów. Drożdże Saccharomyces ssp. charakteryzują się zróżnicowanymi zdolnościami degradacji kwasu jabłkowego 
podczas fermentacji alkoholowej (od 0 do $3 \mathrm{~g} / \mathrm{l}$ ), co uzależnione jest m.in. od temperatury wzrostu szczepów [Vivela-Moura i in. 2008]. Saccharomyces bayanus i Saccharomyces pastorianus syntetyzują kwas jabłkowy, podczas gdy termotolerancyjne szczepy Saccharomyces cerevisiae oraz Saccharomyces paradoxus wykazują zdolności rozkładu kwasu jabłkowego w ilościach nawet do 48\% [Rainieri i in. 1998; Subden i in. 1998].

Drożdże Schizosaccharomyces pombe wykazują zdolność biologicznej degradacji kwasu L-jabłkowego do etanolu w podłożach fermentacyjnych, jednocześnie charakteryzują się odpornością na wysoką kwasowość oraz $\mathrm{SO}_{2}$ [Kunicka, Szopa 1998]. Ocena zdolności biodegradacji L-jabłczanu w moszczach i winach z zastosowaniem drożdży rozszczepkowych była celem doświadczeń prowadzonych przez Redzepovic i in. [2003]. Wykazały one, że szczep Schizosaccharomyces pombe F metabolizuje 90\% kwasu jabłkowego, jednak jego wykorzystanie w winiarstwie ogranicza tworzenie się niekorzystnych cech sensorycznych produktu.

Natomiast promowany do komercyjnego zastosowania w procesie odkwaszania wina gatunek Saccharomyces cerevisiae 71b obniża zawartość L-jabłczanu wyłącznie o 18\% [Redzepovic i in. 2003]. Zdolność danego szczepu do degradacji kwasu jabłkowego uzależniona jest od wewnątrzkomórkowego transportu kwasów dikarboksylowych oraz enzymu jabłkowego metabolizującego L-jabłczan do etanolu i dwutlenku węgla (rys. 2) [Ansanay i in. 1996; Volschenk i in. 1997]. Drożdże Saccharomyces cerevisiae nie są w stanie skutecznie zmniejszyć zawartości kwasu jabłkowego, ponieważ enzym jabłkowy charakteryzuje się niewielkim powinowactwem do substratu $(\mathrm{Km}=50 \mathrm{mM})$. Ponadto niski stopień degradacji L-jabłczanu przez drożdże związany jest z mitochondrialną lokalizacją enzymu jabłkowego u Saccharomyces cerevisiae. W toku dalszych badań podjęto próbę skonstruowania rekombinowanego szczepu drożdży Saccharomyces cerevisiae zawierającego gen Schizosaccharomyces pombe (mae1), mającego charakter przekaźnika przez błonę komórkową kwasów dikarboksylowych oraz dehydrogenazy jabłczanowej (mae2), występującej na plazmidach drożdży winnych. Otrzymane komórki drożdży Sac

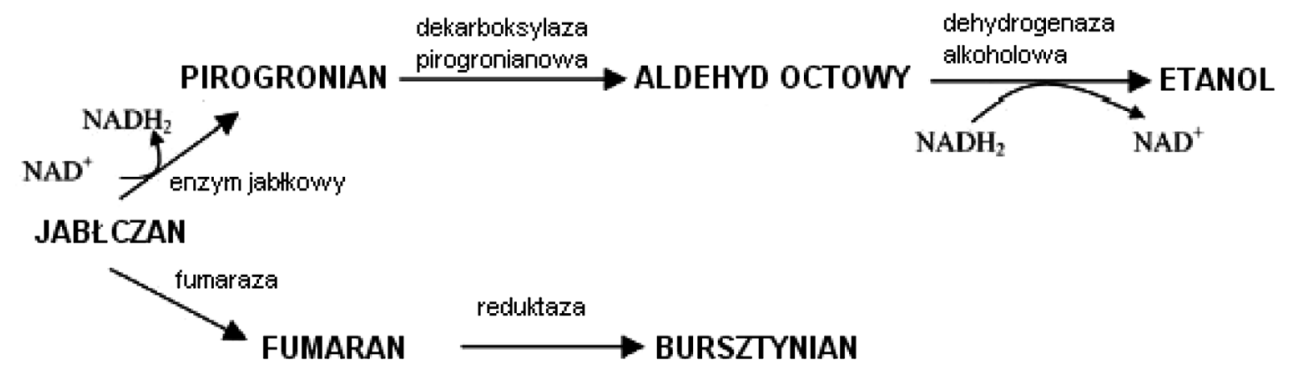

Rys. 2. Rozkład kwasu L-jabłkowego przez drożdże

Źródło: [Redzepovic i in. 2003]. 
charomyces cerevisiae wykazywały zdolność degradacji kwasu L-jabłkowego, nie produkując przy tym ubocznych metabolitów, które mogłyby się przyczynić do obniżenia jakości wina [Volschenk i in. 2001; Redzepovic i in. 2003; Fleet 2008].

Wprowadzenie do procesu fermentacji win mikroorganizmów innych niż Saccharomyces cerevisiae związane jest $\mathrm{z}$ występowaniem interakcji pomiędzy populacjami oraz wytworzeniem niekorzystnych zmian organoleptycznych w finalnym produkcie. Celem doświadczeń przeprowadzonych przez Kunicką i Szopę [1998] było połączenie cech biochemicznych i technologicznych drożdży winiarskich Saccharomyces cerevisiae i rozszczepkowych Schizosaccharomyces pombe, umożliwiających beztlenowy rozkład L-jabłczanu w środowisku fermentacyjnym, jednocześnie z właściwie przeprowadzoną fermentacją alkoholową. Międzyrodzajowe hybrydy otrzymano z wykorzystaniem metody fuzji protoplastów wyżej wymienionych szczepów mikroorganizmów. Na podstawie uzyskanych wyników stwierdzono, że otrzymane mieszańce charakteryzowały się wysoką zdolnością do beztlenowej biodegradacji kwasu L-jabłkowego, wykazując wzrost rozkładu L-jabłczanów w porównaniu do drożdży Schizosaccharomyces pombe. Możliwe jest również profilowanie kwasowości moszczów i win z udziałem mieszanych kultur drożdży [Satora, Tuszyński 2006].

Natomiast doświadczenia przeprowadzone przez Gao i Fleeta [1995] miały na celu wyodrębnienie spośród 30 szczepów drożdży, należących do rodzajów Saccharomyces, Kloeckera, Candida, Schizosaccharomyces i Hansenula, gatunków charakteryzujących się wysoką zdolnością rozkładu kwasów L-jabłkowego oraz L-winowego. Stwierdzono, że szczepy Schizosaccharomyces pombe i Schizosaccharomyces malidevorans degradują 95-99\% L-jabłczanu po 48 godzinach trwania reakcji, w tym 10-34\% kwasu w pierwszych 30 minutach od momentu jej inicjacji. Pozostałe mikroorganizmy rozkładały do $35 \%$ kwasu L-jabłkowego oraz do $25 \%$ kwasu L-winowego w czasie 24-48 godzin.

Szczep Schizosaccharomyces malidevorans, uzyskany na drodze mutagenizacji promieniowaniem UV, metabolizuje kwas jabłkowy znacznie szybciej niż pozostałe gatunki tego rodzaju, wykorzystując niewielkie ilości cukrów występujących w winie. Ponadto wykazuje on odporność na działanie $\mathrm{SO}_{2}$, niskie temperatury i niskie wartości $\mathrm{pH}(\mathrm{pH} 2,8)$. Na uwagę zasługuje fakt, że w przeciwieństwie do Schizosaccharomyces pombe nie tworzy niepożądanych aromatów, dlatego może stanowić alternatywę dla bakterii mlekowych w procesie odkwaszania win [Tul-Krzyszczuk, Kołakowska-Paszkiewicz 2008].

\section{Podsumowanie}

Tradycyjną metodą odkwaszania wina jest fermentacja jabłkowo-mlekowa. Ze względu na nieodłączne problemy jej towarzyszące (produkcja amin biogennych, karbaminianu etylu, zmiana cech organoleptycznych wina) poszukuje się alternatywnych technik redukcji kwasowości win. Odkwaszanie za pomocą szczepów drożdży 
niesie za sobą wiele korzyści. Przyczynia się do degradacji kwasu L-jabłkowego, ale również zmniejsza ryzyko tworzenia niepożądanych związków. Ponadto równoczesne zakończenie fermentacji alkoholowej i procesu odkwaszania zapobiega zepsuciu się wina spowodowanego utlenianiem i hamuje namnażanie szkodliwych mikroorganizmów. Odkwaszanie win za pomocą drożdży daje więc możliwość wprowadzenia lepszych strategii optymalizacji procesu winifikacji. Bioróżnorodność mikroflory drożdżowej owoców winorośli jest niezbędna do uzyskania oryginalnych smaków win, a produkowane przez szczepy enzymy, takie jak pektynazy, $\beta$-glikozydazy, proteazy, esterazy lub lipazy, przyczyniają się do wytworzenia odmianowych aromatów oraz poprawy technologii winifikacji. Alternatywnym rozwiązaniem mogą być też odpowiednio dobrane szczepienia następcze drożdży odkwaszających, we właściwych proporcjach, w stosunku do podstawowej kultury drożdży fermentujących. Zastosowanie szczepów drożdży odkwaszających na skalę przemysłową wymaga jednak dalszych badań, pozwalających na dogłębne poznanie ich fizjologii i metabolizmu.

\section{Literatura}

Ansanay V., Dequin S., Camarasa C., Schaeffer V., Grivet J., Blondin B., Salmon J., Barre P., Malolactic fermentation by engineered Saccharomyces cerevisiae as compared with engineered Schizosaccharomyces pombe, "Yeast" 1996, 12, s. 215-225.

Bartowsky E.J, Borneman A.R., Genomic variations of Oenococcus oeni strains and the potential to impact on malolactic fermentation and aroma compounds in wine, "Applied Microbiology and Biotechnology" 2011, 6.

Bonin S., Zastosowanie mikroorganizmów immobilizowanych $w$ winiarstwie, Żywność. Nauka. Technologia. Jakość 2006, 3, s. 5-15.

Bucher M., Brander K.A., Sbicego S., Mandel T., Kuhlemeier C., Aerobic fermentation in tobacco pollen, "Plant Molecular Biology" 1995, 28, s. 739-750.

Capello M.S., Stefani D., Grieco F., Logrieco A., Zapparoli G., Genotyping by Amplified Fragment Length Pomymorphism and malate metabolism performances of indigenous Oenococcus oeni strains isolated from Primitivo wine, "International Journal of Microbiology" 2008, 127, s. 241-245.

Capone D.L., van Leeuwen K., Pardon K.H., Daniel M.A., Elsey G.A., Coulter A.D., Sefton M.A., Idenfitication and analysis of 2-chloro-6-methylphenol, 2,6-dichlorophenol and indole: causes of taints and off-flavours in wines, Australian "Journal of Grape and Wine Research" 2010, 16, s. $210-217$.

Capozzi V., Russo P., Beneduce L., Weidmann S., Grieco F., Guzzo J., Spano G., Technological properties of Oenococcus oeni strains isolated from typical southern Italian wines, "Letters in Applied Microbiology" 2010, 50, s. 327-334.

Charoenchai C., Fleet G., Henscke P.A., Effects of temperature, $p H$ and sugar concentration on the growth rates and cell biomass of wine yeast, "American Journal of Enology and Viniculture 1998, 49, s. 283-288.

Coloretti F., Zambonelli C., Castellari L., Tini V., Rainieri S., The Effect of DL-Malic Acid on the Metabolism of L-Malic Acid during Wine Alcoholic Fermentation, "Food Technology and Biotechnology" 2002, 40, s. 317-320. 
Coucheney F., Desroche N., Bou M., Tourdot-Marechal R., Dulau L., Guzzo J., A new approach for selection of Oenococcus oeni strains in order to produce malolactic starters, "International Journal of Food Microbiology" 2005, 105, s. 463-470.

Delcourt F., Taillandier P., Vidal F., Strehaiano P., Influence of $\mathrm{pH}$, malic acid and glucose concentrations on malic acid consumption by Saccharomyces cerevisiae, "Applied Microbiology and Biotechnology" 1995, 43, s. 321-324.

Du Toit M., Engelbrecht L., Lerm E., Krieger-Weber S., Lactobacillus: the next generation of malolactic fermentation starter cultures-an overview, "Food and Bioprocess Technology" 2011, 4, s. 876-906.

Fillion L., Ageorges A., Pacaud S., Coutos-Thévenot P., Lemoine R., Romieu C., Derlot S., American Society of Plant Physologists, "Plant Physiology" 1999, 120, s. 1083-1093.

Fleet G.H., Wine Microbiology and Biotechnology, Harwood, Academic Publishers, Switzerland 1994.

Fleet G.H., Wine yeasts for the future, "FEMS Yeast Research" 2008, 8, s. 979-995.

Gao C., Fleet G.H., Degradation of malic and tartaric acids by high density cell suspensions of wine yeasts, "Food Microbiology" 1995, 12, s. 65-71.

Grimaldi A., McLean H., Jiranek V., Identification and partial characterization of glycosidic activities of commercial strains of the lactic acid bacterium, Oenococcus oeni, "American Journal of Enology and Viticulture" 2000, 51, s. 362-369.

Guzzo J., Jobin M.P., Divis C., Increase of sulfite tolerance in Oenococcus oeni by means of acidic adaptation, "FEMS Microbiology Letters" 1998, 60, s. 43-47.

Hornsey I., The Chemistry and Biology of Winemaking, The Royal Society of Chemistry, Cambridge 2007.

Izquierdo Cañas P.M., Garcia Romero E., Gómez Alonso S., Palop Herreros M.L.L., Changes in the aromatic composition of Tempranillo wines during spontaneous malolactic fermentation, "Journal of Food Composition and Analysis" 2008, 21, s. 724-730.

Jackson R.S., Wine Science, Principals and Applications, Academic Press 2008.

Jitjaroen W., Bouphun T., Panjai L., The potential of malolactic fermentation on organic acids degradation in Mao (Antidesma Thwaitesanum Müell.) wine production, "International Journal of Bioscience, Biochemistry and Bioinformatics" 2013, 3, s. 368- 371.

Kennes C., Veiga M.C., Dubourguier H.C., Touzel J.P., Albagnac G., Naveau H., Nyns E.J., Trophic relationships between Saccharomyces cerevisiae and Lactobacillus plantarum and their metabolism of glucose and citrate, "Applied and Environmental Microbiology" 1991, 57, s. 1046-1051.

Kosseva M., Beschkov V., Kennedy J.F., Lloyd L.L., Malolactic fermentation in Chardonnay wine by immobilised Lactobacillus casei cells, "Process Biochemistry" 1998, 33, s. 793-797.

Kučerová J., Široky J., Study of changes organic acids in red wines during malolactic fermentation, Acta Universitatis Agriculturae et Silviculturae Mendelianae Brunensis 2011, 5, s. 145-150.

Kunicka-Styczyńska A., In the search for novel wine yeast with deacidification activity, "Fermentation Technology" 2012, 1.

Kunicka A., Szopa J.S., Otrzymywanie międzyrodzajowych hybrydów drożdży Saccharomyces cerevisiae i Schizosaccharomyces pombe na drodze fuzji protoplastów, „Biotechnologia” 1998, 1, s. 167-177.

López I., López R., Santamaria P., Torres C., Ruiz-Larrea F., Performance of malolactic fermentation by inoculation of selected Lactobacillus plantarum and Oenococcus oeni strains isolated from Rioja red wines, "Vitis" 2008, 47, s. 123-129.

Malherbe S., Tredoux A.G.J., Nieuwoudt H.H., du Toit M., Comparative metabolic profiling to investigate the contribution of O.oeni MLF starter cultures to red wine composition, "Journal of Industrial Microbiology and Biotechnology" 2012, 39, s. 477-494.

Margalit Y., Concepts in Wine Chemistry, Wine Appreciation Guilg Ltd. San Francisco, USA 1997.

Moreno-Arribas M.V., Polo M.C., Wine Chemistry and Biochemistry, Springer Science+Bussines Media 2009. 
Or E., Baybik J., Sadka A., Ogrodovitch A., Fermentative metabolism in grape berries: isolation and characterization of pyruvate decarboxylase cDNA and analysis of its expression throughout berry development, "Plant Science" 2000, 156, s. 151-158.

Osborne J.P., Edwards C.G., Bacteria in winemaking, "Advances in Food and Nutrition Research" 2005, 50, s. 139-177.

Pratelli R., Lacombe B., Torregrosa L., Gaymard F., Romieu C., Thibaud J-B., Sentenac H., A grapevine gene encoding a guard cell $K+$ channel displays developmental regulation in the grapevine berry, "Plant Physiology" 2002, 128, s. 564-577.

Pretorius I.S., Tailoring wine yeast for the new millennium: novel approaches to the ancient art of winemaking, "Yeast" 2000, 16, s. 675-729.

Rainieri S., Zambonelli C., Giucidi P., Castellari L., Characterisation of thermotolerant Saccharomyces cerevisiae hybrids, "Biotechnology Letters" 1998, 20, s. 543-547.

Redzepovic S., Orlic S., Majdak A., Kozina B., Volschenk H., Viljoen-Bloom M., Differential malic acid degradation by selected strains of Saccharomyces during alcoholic fermentation, "International Journal of Food Microbiology" 2003, 83, s. 49-61.

Riberéau-Gayon P., Dubourdieu D., Donèche B., Lonvaud A., Handbook of Enology Volume 1. The Microbiology of Wine and Vinifications, $2^{\text {nd }}$ Edition, John Wiley \& Sons, Ltd 2006.

Riberéau-Gayon P., Glories Y., Maujean A., Dubourdieu D., Handbook of Enology Volume 2. The Chemistry of Wine Stabilization and Treatments, John Wiley \& Sons, Ltd 2006.

Rodriquez S.B., Thornton R.J., Factors influencing the utilization of L-malate by yeasts, FEMS Microbiology Letters 1990, 72, s. 17-22.

Rosi I., Nannelli F., Giovani G., Biogenic amine production by Oenococcus oeni during malolactic fermentation of wines obtained using different strains of Saccharomyces cerevisiae, "Food Science and Technology" 2009, 42, s. 525-530.

Saayman M., Viljoen-Bloom M., The biochemistry of malic acid metabolism by wine yeasts - a review, "South African Journal for Enology and Viticulture" 2006, 2, s. 113- 122.

Satora P., Tuszyński T., Biodiversity of Yeasts During Plum Wegierka Zwykła Spontaneous Fermentation, "Food Technology and Biotechnology" 2005, 3, s. 277-282.

Satora P., Tuszyński T., The influence of Saccharomyces cerevisiae, Kloeckera apiculata and Candida pulcherrima mixed cultures on the selected alcohols formation during model fermentation, The $12^{\text {th }}$ European Congress on Biotechnology, Copenhagen, Denmark, August 2006.

Soyer Y., Koca N., Karadeniz F., Organic acid profile of Turkish white grapes and grape juices, "Journal of Food Composition and Analysis" 2003, 16, s. 629-636.

Sroka P., Tuszyński T., The use of immobilized yeasts in mead wort fermentation, "LWT Food Sciences and Technology" 2007.

Subden R.E., Krizus A., Osothsilp C., Viljoen M., Van Vuren H.J.J., Mutational analysis of malate pathways in Schizosaccharomyces pombe, "Food Research International" 1998, 31, s. 37-42.

Swiegers J. H., Bartowsky E.J., Henschke P.A., Pretorius I.S., Yeast and bacterial modulation of wine aroma and flavor, "Australian Journal of Grape and Wine Research" 2005, 11, s. 139-173.

Terrier N., Sauvage F.X., Ageorges A., Romieu C., Changes in acidity and in proton transport at the tonoplast of grape berries during development, "Planta" 2001, 213, s. 20-28.

Thornton R.J., Rodriquez S.B., Deacidification of red and white wines by a mutant of Schizosaccharomyces malidevorans under commercial winemaking conditions, "Food Microbiology" 1996, 13, s. 475-482.

Tul-Krzyszczuk A., Kołakowska-Paszkiewicz A., Konkurencyjność na rynku wina w Polsce, Stowarzyszenie Ekonomistów Rolnictwa i Agrobiznesu, Roczniki Naukowe 2008, t. X, z. 4.

Winterhalter P., Sefton M.A., Williams P.J., Volatile C13 norisoprenoid compounds in Riesling wine are generated from multiple precursors, "Journal of Agriculture and Food Chemistry" 1990, 41, s. 277-283. 
Vivela-Moura A., Schuller D., Mendes-Faia A., Corte-Real M. Reduction of volatile acidity of wines by selected yeast strains, "Applied Microbiology and Biotechnology” 2008, 80, s. 881-890.

Volschenk H., Viljoen-Bloom M.H., Differential malic acid degradation by selected strains of Saccharomyces during alcoholic fermentation, "International Journal of Food Microbiology" 2006, 83, s. 49-61.

Volschenk H., Viljoen M., Grobler J., Petzold B., Bauer F., Subden R.E., Young R.A., Lonvaud A., Denayrolles M., van Vuuren H.J.J., Engineering pathways for malate degradation in Saccharomyces cerevisiae, "Nature Biotechnology" 1997, 15, s. 253-257.

Volschenk H., Viljoen-Bloom M., Subden R.E., van Vuuren H.J.J., Malo-ethanolic fermentation in grape must by recombinant strains of Saccharomyces cerevisiae, "Yeast" 2011, 18, s. 63-970.

Volschenk H., van Vuuren H.J.J., Viljoen-Bloom M., Malic Acid in Wine: Origin, Function and Metabolism during Vinification, "South African Journal for Enology and Viticulture" 2006, 27, s. 123-136.

Zoecklein B.W., Fugelsang K.C., Gumo B.H., Nury F.S., Wine Analysis and Production, Chapmann \& Hall, New York 1995.

\section{BIOLOGICAL DEACIDIFICATION METHODS OF WINES}

Summary: The balance between sugar and acid content is the most important factor in the production of high quality wines. L-malate and L-tartrate play a crucial role in the winemaking process, influence the organoleptic properties and biochemical, physical and microbial stability of wine. The deacidification of grape must and wine is often an essential part of its production, especially in areas with unfavorable climatic conditions, which also include Poland. Malolactic fermentation induced by lactic acid bacteria (LAB) effectively reduces the wine acidity, but it contributes to change in character and to the production of undesired compounds, such as biogenic amines and ethyl carbamate. The deacidification of wine using yeast strains is an alternative for it. Taking into consideration the genetic diversity and variability of yeast cultures characterized by different reduction effectiveness of malic acid in grape musts and wines, the strains that allow biodegradation of L-malic acid with properly conducted fermentation and maturation process deserve special attention. The deacidification of wines with yeast makes it possible not only to reduce the acidity, but also to get the desired flavor and aroma components, forming the sensory quality of the final product.

Keywords: wine deacidification, LAB, yeasts, L-malic acid. 